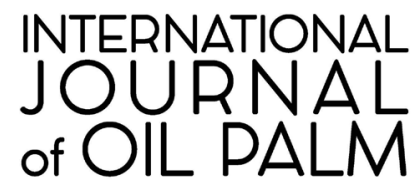

Volume 2, Number 3, September 2019

Page 120-130

ISSN: 2599-3496 print

ISSN: 2614-2376 online

\title{
Study on Characteristics of Oil Palm Empty Fruit Bunch to Predict Condensation Temperature of Tar from its Pyrolysis Gas
}

\author{
Joni $^{1,2}$, Armansyah Halomoan Tambunan ${ }^{1 *}$, Radite Praeko Agus Setiawan, \\ Kiman Siregar ${ }^{3}$ \\ ${ }^{1}$ Department of Mechanical and Biosystem Engineering, IPB University, Bogor, Indonesia. \\ ${ }^{2}$ Department of Mechanical Engineering, University of Cendrawasih \\ ${ }^{3}$ Syiah Kuala University, Banda Aceh 23111, Indonesia.
}

\begin{abstract}
Palm oil is one type of plants that has various advantages since almost all parts of the plant, such as trunk, empty fruit bunch (EFB) and the extracted oil, can be utilized as energy. Utilization of EFB for energy, especially the use of combustible gas as direct feed of combustion engines to generate electricity is still rarely used. This is related to the water content and existence of tar in the syngas which is unfavorable. To overcome the problem, information on the characteristics and thermophysical properties, such as dew point, of tar in the pyrolysis of EFB is indispensable. In this study, the kind and quantity of tar was experimentally measured and dew point of the tar was calculated. Three EFB samples were taken from three different environmental conditions, namely samples EFB1, EFB2 and EFB3, to be analyzed. The elemental and proximate analysis as well as GCMS pyrolysis test of the samples were then used to characterize tar in the syngas and to determine its thermo-physical properties in terms of its dew point. The elemental analysis of the EFB samples showed disparity of its content, which was around $52.08 \pm 7.59 \%(\mathrm{C}), 7.05 \pm 0.53 \%(\mathrm{H}), 2.28 \pm 0.43 \%(\mathrm{~N}), 0.35 \pm 0.36 \%(\mathrm{~S})$ and $34.84 \pm 4.45 \%(\mathrm{O})$. Likewise, the proximate analysis showed differences around $4.49 \pm 2.60 \%$ (MC), $5.80 \pm 1.97 \%$ fixed carbon (FC) and $73.44 \pm 3.78 \%$ volatile matter (VM). From the elemental and proximate analysis, it can be predicted that tar compounds produced from pyrolysis of the EFB at a temperature of $400{ }^{\circ} \mathrm{C}$, was in the form of mixed oxidation compounds (mixed oxygenates). The compounds were classified as the first tar compound (class 2) consisting of phenols (ketones, phenol and guaiacol). The dew point temperature and the concentration of the tar in its pyrolysis gas were predicted to be $204.22{ }^{\circ} \mathrm{C}$, tar $1720.79 \mathrm{mg} \mathrm{Nm}^{3-1}$ (sample EFB1); $256.02{ }^{\circ} \mathrm{C}$, tar $92.97 \mathrm{mg} \mathrm{Nm}^{3-1}$ (sample EFB2); and $154.85^{\circ} \mathrm{C}$, tar $359.02 \mathrm{mg} \mathrm{Nm}^{3-1}$ (sample EFB3), respectively. This information can be useful in designing the tar elimination devices from the pyrolysis gas.
\end{abstract}

Keywords: condensation temperature, oil palm empty fruit bunch, pyrolysis, tar compound, tar concentration

\footnotetext{
${ }^{*}$ Corresponding author:

Department of Mechanical and Biosystem Engineering, Faculty of Agricultural Engineering and Technology, IPB University, Bogor 16680, Indonesia.

Email: ahtambun@gmail.com
} 


\section{INTRODUCTION}

Empty fruit bunch (EFB) is a by-product of oil palm mill, with great potential to be applied in industrial sectors, including material, chemical and energy sectors (Abdulrazik et al. 2017). The EFB contains cellulose, hemicellulose and lignin, with composition range of $23.7-65.0 \%$, $20.6-33.5 \%$ and $14.1-30.45 \%$, respectively (Law et al. 2007). EFB can be used directly as energy source by direct combustion, or converted into syngas for using in internal combustion engine.

Gasification is one of the available conversion technology to convert biomass into syngas. Gasification is a series of processes, including pyrolysis, oxidation, reduction and drying. Pyrolysis is the main process to convert the biomass structure into simple structure and gases. The gas produces is typically a mixture of hydrogen $\left(\mathrm{H}_{2}\right)$, carbon monoxide $(\mathrm{CO})$, methane $\left(\mathrm{CH}_{4}\right)$ and carbon dioxide $\left(\mathrm{CO}_{2}\right)$ and several other compounds in the form of tar.
Tar is the main contaminant in the syngas, which becomes problem in its uses as engine fuel. Figure 1 shows the diagrammatic process flow of thermochemical reaction in gasification process. It is shown that tar formation cannot be avoided and will be condensed at temperature below $400{ }^{\circ} \mathrm{C}$. If the process temperature drops below the dew point, then tar causes some problems even at low concentrations.

Tar is generally in the form of aerosols and polymerization with more complex structures. It is described as a substance with dark colour, oily and thick. Generally, tar is defined as a mixture of condensed hydrocarbon complexes, which consists of a single ring (aromatic compound), 5-ring together with other oxygen-containing hydrocarbons (aromatic hydrocarbons) and polyclic complex aromatic hydrocarbons (PAHs). Tar comes from the organic part of biomass through a series of complex thermochemical reactions, such as chemolysis, oxidation, depolymerization and polymerization, which

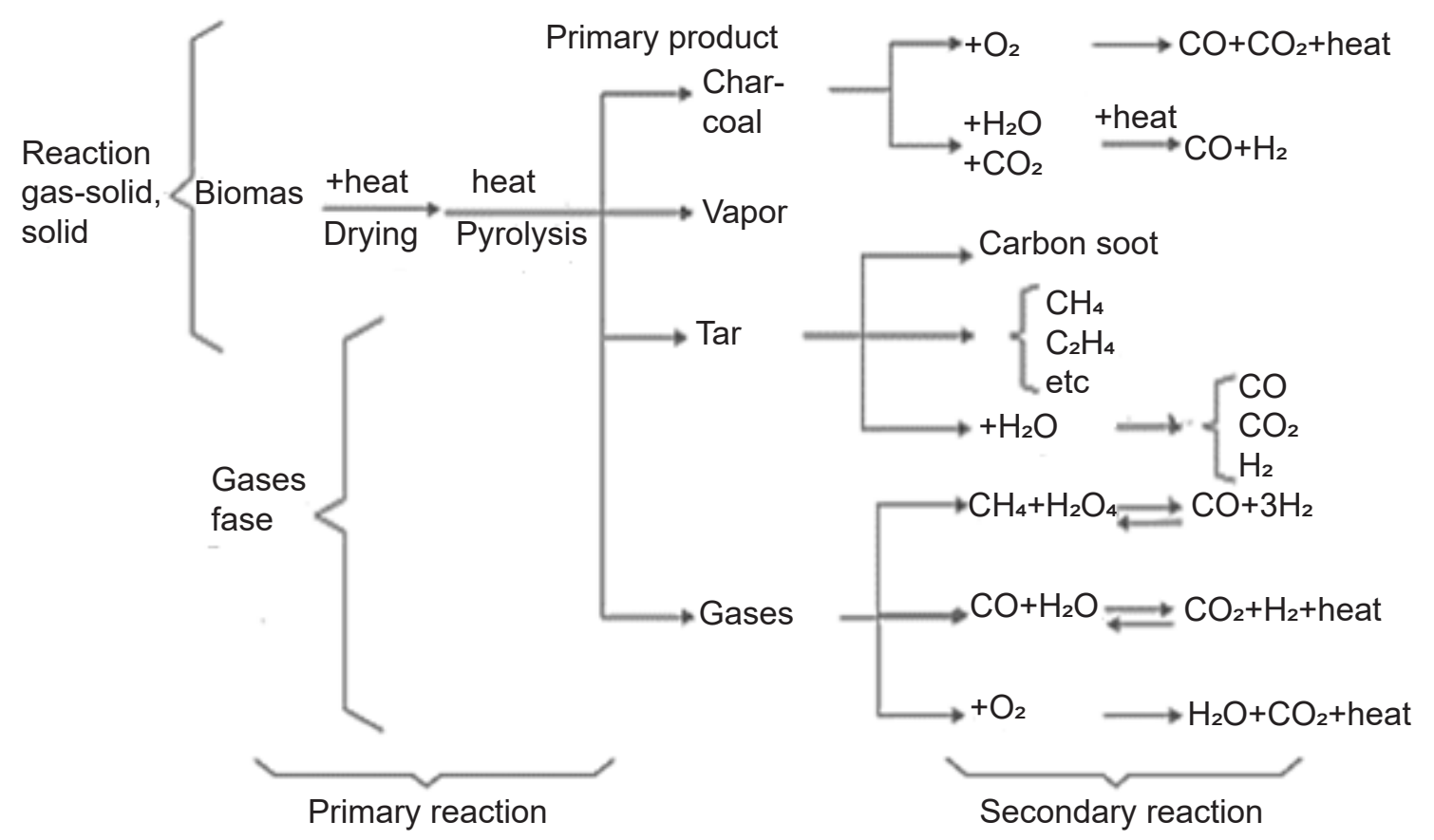

Figure 1 Biomass thermochemical reaction (Richardson et al. 2015). 
Joni et al.

occurs during gasification of cellulose, hemicellulose and lignin in the reactor. Lignin decomposition yields a much higher tar than cellulose and hemicellulose decomposition.

In addition, at a gasification temperature of $800{ }^{\circ} \mathrm{C}$ an extraordinary difference was observed between tar compositions. The main components, besides $\mathrm{PAH}$, after decomposition of lignin are phenols and their derivatives. Benzene, toluene, ethylbenzene, xylene isomer (BTEX) and other hydrocarbons, consisting mainly of ethers, esters and furans, are the main products of cellulose and hemicellulose gasification. The quality and quantity of tar depends, in addition to the nature of the fuel, on the gasification process parameters (temperature, pressure, oxidizing media, type of gasifier, etc.).

Tar is grouped according to 5 rings classes, namely: heavy (not detected by GC); heterocyclic aromatics; mild aromatics (1 ring); lightweight $\mathrm{PAH}$ (2-3 rings); and heavy $\mathrm{PAH}$ (4-7 rings). The group depends on process temperature, where at $400{ }^{\circ} \mathrm{C}$ there exists a mixture of oxidation compounds; at $500{ }^{\circ} \mathrm{C}$ exist phenol and esters; at $600{ }^{\circ} \mathrm{C}$ exists alkyl and phenolic; at $700{ }^{\circ} \mathrm{C}$ exists heterocyclic and esters; at $800{ }^{\circ} \mathrm{C}$ exists mild $\mathrm{PAH}$; and at $900{ }^{\circ} \mathrm{C}$ exists severe PHA. Besides, type of biomass (depend on its physical and chemical properties) also affect the type of tar in the produced gas (Morf et al. 2002).

This objective of this study is to identify and classify tar compounds exists in the pyrolysis gas of oil palm empty fruit bunch, and predict its condensation temperature. The result of this study is required for the development of tar compound cleaning tools for further applications.

\section{MATERIAL AND METHODS}

\section{Tar Identification}

The material used in this research is oil palm empty fruit bunches (EFB) obtained from a palm oil processing factory in Cikasungka, West Java, Indonesia. Three samples, namely EFB1, EFB2 and EFB3, were analysed. EFB1 and EFB2 were obtained directly from the factory with new conditions, while EFB3 was obtained from the waste pile and has been wasted for 2 months around the factory. EFB1 was dried naturally and EFB2 was oven dried at temperature $105^{\circ} \mathrm{C}$ in 24 hours.

Ultimate and proximate analysis were performed to the samples, with compliance to ASTM standards. The standard include ASTM D5373 for carbon, hydrogen, nitrogen test; ASTM D3176 for oxygen test; ASTM D4239 for sulfur test; ASTM D3173 for moisture content test in dry air; ASTM D3174 for ash content test; ASTM D3175 for volatile test; ASTM D3172 for fixed carbon test; and ASTM D5865 for heating value.

Produced gas and tar identification was performed using pyrolysis-GCMS, as shown in Figure 2. It consists of pyrolysis reactor and GCMS, with their respective types are PY-2020iS and GCMS-QP2010 Shimadzu. EFB were sample $(0.1 \mu \mathrm{g})$ was placed in a container of the reactor and processed at a temperature of $400{ }^{\circ} \mathrm{C}$ without catalyst. Helium gas $(\mathrm{He})$ carrier was used to channel the pyrolysis gas. The resulting decomposition product was transferred to a separate separation column for identification by pyrogram. The individual gas components in the pyrogram were identified continuously using mass spectra. The test results were obtained in the form of diagrams and concentration data and types of compounds. 


\section{Condensation Temperature Prediction}

Condensation of temperature can be calculated from the vapor pressure of the gas, which is burnable when it is in a single compound or consists of several components in the compound using equation 1. Here, the behaviour of the tar vapor is assumed as an ideal gas (Rabou et al. 2009).

$$
22400 \times \frac{\mathrm{C}_{\mathrm{tar}} \times \mathrm{T}_{\mathrm{dp}}}{273 \times \mathrm{MW} \times \mathrm{P}_{d p}(\mathrm{~T})}=1
$$

where, $\mathrm{C}_{\mathrm{tar}}$ is compound concentration of $\operatorname{tar}\left(\mathrm{g} \mathrm{Nm}^{3-1}\right) ; \mathrm{T}_{\mathrm{dp}}$ is dew point temperature $(\mathrm{K})$; $\mathrm{MW}$ is molecular weight of compounds $\left(\mathrm{g} \mathrm{mol}^{-1}\right) ; \mathrm{P}_{\text {dp }}(T)$ is dew point pressure at designated temperature (atm); ideal molar volume of gas is $22.400 \mathrm{~m}^{3}$ $\mathrm{mol}^{-1}$.

The saturated vapor pressure of a gas containing tar can be calculated using equation 2 , and dew point pressure $\left(P_{d p}\right)$ is expressed as in equation 3.

$$
\begin{aligned}
& P_{s w}=10^{\left(A-\frac{B}{T+C}\right)} \\
& P_{d p}=\frac{1}{\sum_{i=1}^{k}\left(\frac{y_{i}}{P_{s w}}\right)}
\end{aligned}
$$

where, A, B, C are Antoine constant; T is pyrolysis temperature $(\mathrm{K})$; yi is steam volume fraction (\%); $\mathrm{P}_{\mathrm{sw}}$ is saturated vapour pressure $(\mathrm{mmHg})$.

Relationship between liquid volume fraction $\left(x_{i}\right)$ and steam volume fraction $\left(y_{i}\right)$ of the tar is shown in equation 4.

$$
\mathrm{X}_{\mathrm{i}}=\frac{\mathrm{y}_{\mathrm{i}}}{\mathrm{P}_{\mathrm{sw}}} \times \mathrm{P}_{\mathrm{dp}}
$$

\section{RESULTS AND DISCUSSION}

\section{Ultimate and Proximate Analysis}

Table 1 shows the comparison of ultimate and proximate analysis for EFB1, EFB2 and EFB3 samples. The proximate analysis is displayed in wet bases (wb), while the ultimate analysis in dry bases $(\mathrm{db})$. The composition of the EFB was found to be $52 \pm 8 \%$ (C), $7.1 \pm 0.5 \%$ $(\mathrm{H}), \quad 2.3 \pm 0.4 \%(\mathrm{~N}), \quad 0.5 \pm 0.2 \%(\mathrm{~S})$ and $35 \pm 4(0)$; while the ash was $6 \pm 2 \%$, fixed carbon (FC) $17 \pm 1 \%$ and volatile matter (VM) $73 \pm 4 \%$. Variation of the data was high due to many factors, including the age of the plant, harvest time, etc. The same data variation also found in other

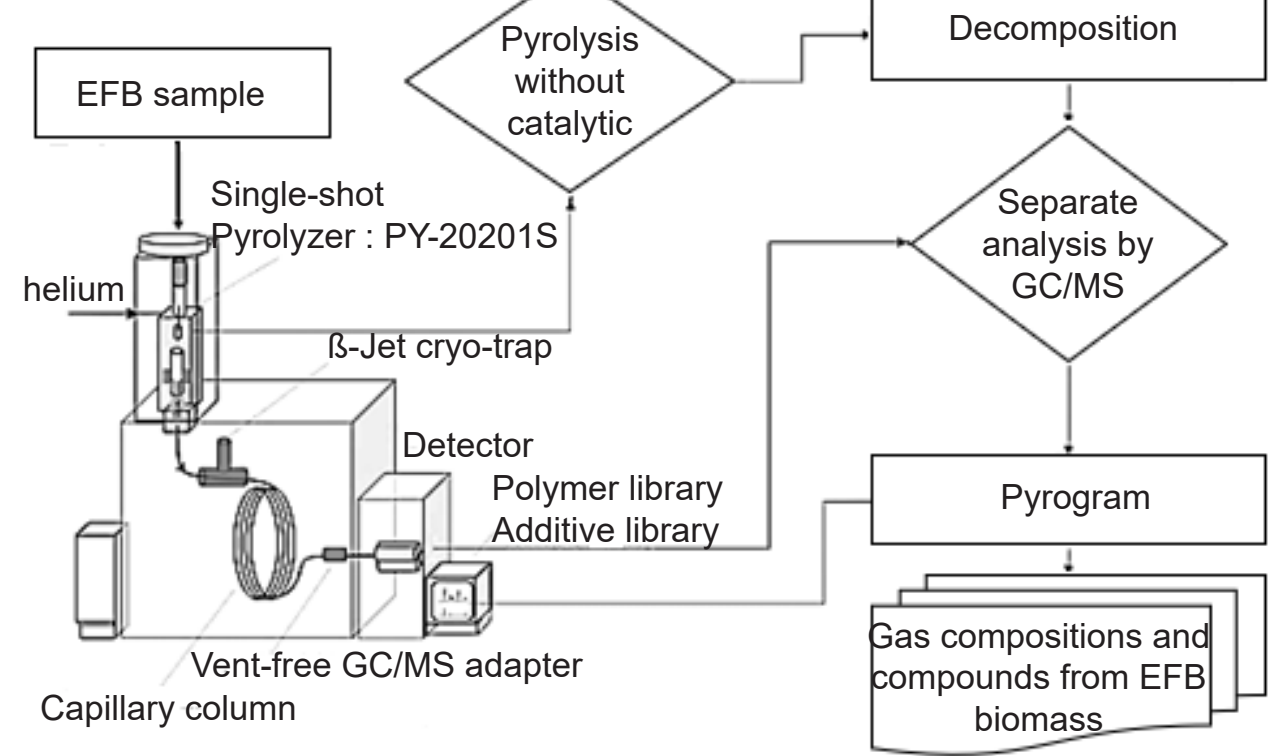

Figure 2 Flow chart of biomass gas characterization using Pyrolysis-GCMS (Shin et al. 2011). 
literatures, which is summarized in Table 2 (C 48 $\pm 5 \%, \mathrm{H} 6.4 \pm 1 \%, \mathrm{~N} 0.8 \pm 0.6 \%$, S $0.3 \pm 0.3 \%$ and $\mathrm{O} 44 \pm 6$; while the ash was $5 \pm 3 \%$, FC $14 \pm 4 \%$ and VM $85 \pm 6 \%$ ). The value of higher heating value (HHV) of the sample was also measured and shown in the. The HHV was in the range $20 \pm 2 \mathrm{MJ}$ $\mathrm{kg}^{-1}$. Normally, higher content of carbon,

Table 1 Main analysis and results of direct EFB tests

\begin{tabular}{|c|c|c|c|c|c|c|c|c|c|}
\hline \multirow{2}{*}{ Sample } & \multicolumn{3}{|c|}{$\begin{array}{c}\text { Proximate nalysis } \\
(\% \mathrm{wb})\end{array}$} & \multicolumn{5}{|c|}{$\begin{array}{l}\text { Ultimate analysis } \\
\qquad(\% \mathrm{db})\end{array}$} & \multirow{2}{*}{$\begin{array}{c}\mathrm{HHV} \\
=\left(\mathrm{MJ} \mathrm{kg}^{-1}\right)\end{array}$} \\
\hline & Ash & $\mathrm{FC}$ & VM & C & $\mathrm{H}$ & $\mathrm{N}$ & $S$ & $\mathrm{O}$ & \\
\hline EFB1 & 7.40 & 18.25 & 89.20 & 60.40 & 7.60 & 2.20 & na & 29.80 & 18.74 \\
\hline EFB2 & 3.74 & 16.23 & 89.93 & 50.32 & 7.02 & 1.89 & 0.72 & 40.05 & 21.54 \\
\hline EFB3 & 7.05 & 18.73 & 83.73 & 45.53 & 6.54 & 2.74 & 0.34 & 44.81 & 18.72 \\
\hline Mean & 6.06 & 17.73 & 87.62 & 52.08 & 7.05 & 2.28 & 0.35 & 34.84 & 19.67 \\
\hline St.D & 2.02 & 1.33 & 3.39 & 7.59 & 0.53 & 0.43 & 0.27 & 4.45 & 1.62 \\
\hline
\end{tabular}

Tabel 2 The results of test are based on ultimate and proximate analysis data in dry basis (db) of EFB

\begin{tabular}{|c|c|c|c|c|c|c|c|c|c|}
\hline \multicolumn{3}{|c|}{ Proximate analysis ( $\mathrm{db} \%$ ) } & \multicolumn{5}{|c|}{ Ultimate analysis (db \%) } & \multirow{2}{*}{$\begin{array}{c}\mathrm{HHV} \\
\left(\mathrm{MJ} \mathrm{kg}^{-1}\right)\end{array}$} & \multirow{2}{*}{ Reference } \\
\hline Ash & $\mathrm{FC}$ & VM & $\mathrm{C}$ & $\mathrm{H}$ & $\mathrm{N}$ & $S$ & $\mathrm{O}$ & & \\
\hline 3.31 & 15.44 & 86.16 & 48.79 & 7.33 & 0.00 & 0.68 & 43.20 & 18.96 & Yang et al. 2004 \\
\hline 3.29 & 8.87 & 87.14 & 48.79 & 7.33 & 0.00 & 0.68 & 43.18 & 18.96 & Hamzah 2008 \\
\hline 4.29 & 12.84 & 85.66 & 43.21 & 7.42 & 0.86 & 0.75 & 47.76 & 18.66 & Khor et al. 2009 \\
\hline 4.98 & 16.13 & 83.33 & 40.93 & 5.42 & 1.56 & 0.31 & 51.78 & 16.80 & Idris et al. 2010 \\
\hline 5.82 & 9.52 & 85.37 & 49.07 & 6.48 & 0.70 & 0.10 & 43.65 & 19.35 & Abdullah et al. 2011 \\
\hline 8.92 & 11.69 & 78.78 & 50.00 & 6.50 & 0.62 & 0.12 & 34.82 & 19.74 & Erlich et al. 2011 \\
\hline 6.87 & 13.02 & 83.33 & 44.30 & 6.20 & 0.44 & 0.09 & 48.94 & 19.24 & Kerdsuwan et al. 2011 \\
\hline 4.88 & 8.75 & 86.58 & 43.52 & 5.72 & 1.20 & 0.66 & 48.90 & 15.22 & Lahijani et al. 2011 \\
\hline 7.77 & 19.79 & 87.15 & 45.00 & 6.40 & 0.25 & 1.06 & 47.30 & 18.10 & Omar et al. 2011 \\
\hline 3.18 & 13.00 & 93.71 & 53.78 & 4.37 & 0.35 & 0.00 & 41.50 & 17.08 & Sukiran et al. 2011 \\
\hline 5.26 & 16.65 & 90.38 & 47.65 & 5.20 & 1.82 & 0.36 & 44.97 & 16.80 & Idris et al. 2012 \\
\hline 3.64 & 13.32 & 90.10 & 46.62 & 6.45 & 1.21 & 0.04 & 45.66 & 17.02 & Mohammed et al. 2012 \\
\hline 14.50 & 12.14 & 78.23 & 53.22 & 6.25 & 0.97 & 0.48 & 39.08 & 17.61 & Ruengvilairat 2012 \\
\hline 5.82 & 9.52 & 85.37 & 49.07 & 6.48 & 0.70 & 0.10 & 43.65 & 19.35 & Geng 2013 \\
\hline 4.97 & 16.18 & 84.95 & 43.15 & 5.73 & 1.20 & 0.04 & 49.88 & 17.57 & Nyakumaa et al. 2013 \\
\hline 4.12 & 13.22 & 92.65 & 44.71 & 6.76 & 0.21 & 0.41 & 47.91 & 21.77 & Alias et al. 2014 \\
\hline 3.21 & 22.05 & 93.08 & 45.36 & 6.43 & 0.32 & 0.41 & 47.48 & 18.51 & Alias et al. 2014 \\
\hline 4.97 & 16.18 & 84.95 & 43.14 & 5.73 & 1.20 & 0.05 & 49.88 & 17.57 & Nyakumaa et al. 2015 \\
\hline 7.50 & 18.59 & 82.93 & 44.80 & 7.30 & 0.65 & 0.47 & 46.78 & 17.94 & Chew et al. 2016 \\
\hline 4.11 & 14.74 & 88.65 & 66.17 & 9.54 & 1.51 & 0.06 & 22.72 & 18.72 & Raju et al. 2016 \\
\hline 2.66 & 5.90 & 87.89 & 45.44 & 6.22 & 1.58 & 0.36 & 46.40 & 17.00 & Tang et al. 2017 \\
\hline 3.39 & 12.03 & 68.05 & 46.71 & 5.97 & 0.07 & 0.03 & 47.22 & 16.00 & Lisandy et al. 2017 \\
\hline 3.50 & 10.08 & 74.72 & 45.90 & 6.10 & 0.43 & 0.13 & 47.44 & 15.50 & Han \& Kim 2018 \\
\hline 4.13 & 15.40 & 91.79 & 55.59 & 6.30 & 1.82 & 0.07 & 36.23 & 20.38 & Lee et al. 2018 \\
\hline 8.61 & 19.36 & 86.20 & 52.74 & 5.73 & 1.43 & 0.12 & 39.98 & 17.62 & Kim et al. 2019 \\
\hline 5.35 & 13.78 & 85.49 & 47.91 & 6.37 & 0.84 & 0.30 & 44.25 & 18.06 & Mean \\
\hline 2.60 & 3.90 & 5.84 & 5.34 & 0.96 & 0.58 & 0.29 & 6.17 & 1.52 & St.D \\
\hline
\end{tabular}


hydrogen and sulphur will lead to higher value of $\mathrm{HHV}$, while in contrary, oxygen content will lower the value.

Fixed carbon (FC) is an indicator of the carbon content contained in biomass. Its value is influenced by the age of the biomass itself. Biomass that is harvested too fast has a low fixed carbon content, whereas lately harvested will have higher content of fixed carbon. Consequently, this also affects concentration of other components such as ash content and volatile matter.

\section{Pyrolysis of EFB}

Based on the pyrolysis-GCMS measurements, there was 32-40 compound species produced after $30-45$ minutes of the process. The compound was dominated by fatty acids and some of them were phenol compounds. These compounds can be grouped into class 2 (Paul et al. 1994; Milne et al. 1998; Morf et al. 2002) and belongs to the category of oxygen- ate mixtures which are commonly found in gasification or pyrolysis upper layers at $400{ }^{\circ} \mathrm{C}$. The results of this grouping are shown in Table 3, Table 4 and Table 5, for each sample of EFB1, EFB2 and EFB3, respectively.

If the compound, which is still in the form of an oxygenate mixture, is recirculated in a reactor or combustion chamber with temperatures above $600{ }^{\circ} \mathrm{C}$, a number of aromatic hydrocarbons with 1 and 2 rings could be obtained in the form of poly-aromatic hydrocarbon (PAH). The greater the number of carbon chain bonds in a hydrocarbon compound, the more energy is required to break this chain into more simple compounds.

Decomposition of cellulose and hemicellulose by pyrolysis at temperature range of $329-350{ }^{\circ} \mathrm{C}$ results in depolymerization and dehydration process to form furfuran compounds and 2-furancarboxaldehyde. While, at higher temperature range of $400-471{ }^{\circ} \mathrm{C}$, the $\mathrm{C}=\mathrm{O}$ bond breaks and

Table 3 Group of individual organic compounds in tar compounds produced from pyrolysis of EFB1 sample

\begin{tabular}{|c|c|c|c|c|c|c|}
\hline Tar classes & Compounds & $\begin{array}{c}\text { Conc. } \\
(\%)\end{array}$ & Name & $\begin{array}{c}\text { Chemical } \\
\text { formula }\end{array}$ & $\begin{array}{c}\mathrm{MW} \\
\left(\mathrm{g} \mathrm{mol}^{-1}\right)\end{array}$ & CAS \\
\hline \multirow{6}{*}{$\begin{array}{l}\text { The primary } \\
\text { group of tar } \\
\text { compounds } \\
\text { (Class } 2 \text { ) }\end{array}$} & Furan & 0.01 & $\begin{array}{l}\text { 2-Furanmethanol (CAS) Furfuryl } \\
\text { alcohol }\end{array}$ & $\mathrm{C}_{5} \mathrm{H}_{6} \mathrm{O}_{2}$ & 98 & $98-00-0$ \\
\hline & Guaiacol & 0.06 & Phenol, 2-methoxy-(CAS) Guaiacol & $\mathrm{C}_{7} \mathrm{H}_{8} \mathrm{O}_{2}$ & 124 & $90-05-1$ \\
\hline & Phenols & 0.07 & Phenol (CAS) Izal & $\mathrm{C}_{6} \mathrm{H}_{6} \mathrm{O}$ & 94 & $108-95-2$ \\
\hline & syringol & 0.10 & $\begin{array}{l}\text { Phenol, 2,6-dimethoxy- (CAS) 2,6- } \\
\text { Dimethoxyphenol }\end{array}$ & $\mathrm{C}_{8} \mathrm{H}_{10} \mathrm{O}_{3}$ & 154 & $91-10-1$ \\
\hline & 4-Ethylsyringol & 0.02 & $\begin{array}{l}\text { Phenol, 4-ethyl-2-methoxy- (CAS) } \\
\text { 2,6-Dimethoxyphenol }\end{array}$ & $\mathrm{C}_{10} \mathrm{H}_{14} \mathrm{O}_{3}$ & 182 & $14059-92-8$ \\
\hline & $\begin{array}{l}\text { Mixed } \\
\text { oxygenates }\end{array}$ & 0.07 & 2-Propanone, 1-hydroxy-(CAS) Acetol & $\mathrm{C}_{3} \mathrm{H}_{6} \mathrm{O}_{2}$ & 74 & $116-09-6$ \\
\hline
\end{tabular}

Table 4 Group of individual organic compounds in tar compounds produced from pyrolysis of EFB2 sample

\begin{tabular}{|c|c|c|c|c|c|c|}
\hline Tar classes & Compounds & $\begin{array}{c}\text { Conc. } \\
(\%)\end{array}$ & Name & $\begin{array}{c}\text { Chemical } \\
\text { formula }\end{array}$ & $\begin{array}{c}\mathrm{MW} \\
\left(\mathrm{g} \mathrm{mol}^{-1}\right)\end{array}$ & CAS \\
\hline \multirow{3}{*}{$\begin{array}{l}\text { The primary } \\
\text { group of tar } \\
\text { compounds } \\
\text { (Class 2) }\end{array}$} & Acid & 0.01 & Hepatonic acid (CAS) Heptoic acid & $\mathrm{C}_{7} \mathrm{H}_{14} \mathrm{O}_{2}$ & 130 & $111-14-8$ \\
\hline & Guaiacol & 0.01 & 2-Methoxy-4-methylphenol & $\mathrm{C}_{8} \mathrm{H}_{10} \mathrm{O}_{2}$ & 138 & $93-51-6$ \\
\hline & Guaiacol & 0.01 & $\begin{array}{l}\text { Phenol, 4-ethyl-2-methoxy- (CAS) } \\
\text { p-Ethylguaiacol }\end{array}$ & $\mathrm{C}_{9} \mathrm{H}_{12} \mathrm{O}_{2}$ & 152 & $2785-89-9$ \\
\hline
\end{tabular}


forms a meth-methoxy (S)-2-furanethanol and tetrahydro-2,5-dimethoxy-furan compound. Whereas, lignin decomposition consists of relatively complex depolymerization, dehydration, cracking and hydrogenation process. Lignin is depolymerized and dehydrated to propenyl-guaiacol at low temperature range of $329-350{ }^{\circ} \mathrm{C}$. Propenyl-guaiacol can then be hydrogenated to propyl-guaiacol at $350-400$ ${ }^{\circ} \mathrm{C}$. Lignin and guaiacol cracks occur at $350-471^{\circ} \mathrm{C}$ and the position of the damaged $\mathrm{C}-\mathrm{C}$ bond is strongly related to temperature. In addition, the breaking of the $\mathrm{C}_{\beta}-\mathrm{C}_{\mathrm{Y}}$ bond occurs at $350{ }^{\circ} \mathrm{C}$, followed by the breaking of the $\mathrm{C}_{\alpha}-\mathrm{C}_{\beta}$ bond at $400{ }^{\circ} \mathrm{C}$ compared to the $\mathrm{C}_{4}-\mathrm{C}_{\alpha}$ bond at $450{ }^{\circ} \mathrm{C}$. Finally, cleavage of $\mathrm{C}-\mathrm{O}-\mathrm{CH} 3$ occurs at $471^{\circ} \mathrm{C}$ (Zhang et al. 2017).

\section{Condensation Temperature}

Condensation temperature is one of the physical properties possessed by a mixture of two or more types of compounds in a gas. This temperature indicator is used to predict when the gas mixture will condense under predetermined conditions. Thus, it can be assumed that tar will first condense at this temperature. From the identification data of pyrolysis gas composition categorized as tar com- pounds, as shown in Table 3, Table 4 and Table 5, the condensation temperature can be predicted using equations 1 to 4 . The constant values of Antoine (A, B and $C$ ) is determined based on the type of the compound, as in Table 6. The results of the analysis to predict saturated vapor pressure, condensation pressure and condensation temperature of compounds can be seen also in the table.

Concentration of the compound at the calculated condensation temperature were $1720.79 \mathrm{mg} \mathrm{Nm}^{3-1}, 92.97 \mathrm{mg} \mathrm{Nm}^{3}$ ${ }^{-1}$ and $359.02 \mathrm{mg} \mathrm{Nm}^{3-1}$, for each sample respectively. Relationship of the concentration and condensation temperature of tar compounds in each of EFB samples can be seen in Figure 3. The difference in the condensation temperature and tar concentration in the EFB sample is influenced by the physical properties of the EFB. This study found that condensation temperature of sample EFB1 was 204.22 ${ }^{\circ} \mathrm{C}$ with tar concentration of $1720.79 \mathrm{mg}$ $\mathrm{Nm}^{3-1}$, sample EFB2 was $256.02{ }^{\circ} \mathrm{C}$ with tar concentration $92.97 \mathrm{mg} \mathrm{Nm}^{3-1}$, sample EFB3 was $154.85^{\circ} \mathrm{C}$ with tar concentration $359.02 \mathrm{mg} \mathrm{Nm}^{3-1}$. For the purpose of eliminating the tar from the pyrolysis gas, it needs to be condensed at that temperature range in a condenser.

Table 5 Group of individual organic compounds in tar compounds produced from pyrolysis of EFB3 sample

\begin{tabular}{|c|c|c|c|c|c|c|}
\hline Tar classes & Compounds & $\begin{array}{c}\text { Conc. } \\
(\%)\end{array}$ & Name & $\begin{array}{c}\text { Chemical } \\
\text { formula }\end{array}$ & $\begin{array}{c}\mathrm{MW} \\
\left(\mathrm{g} \mathrm{mol}^{-1}\right)\end{array}$ & CAS \\
\hline \multirow{5}{*}{$\begin{array}{l}\text { The primary } \\
\text { group of tar } \\
\text { compounds } \\
\text { (Class } 2 \text { ) }\end{array}$} & Phenols & 0.0210 & Phenol (CAS) Izal & $\mathrm{C}_{6} \mathrm{H}_{6} \mathrm{O}$ & 94 & $108-95-2$ \\
\hline & Guaiacols & 0.0029 & $\begin{array}{l}\text { 2-Methoxy- } \\
\text { 4-methylphenol }\end{array}$ & $\mathrm{C}_{8} \mathrm{H}_{10} \mathrm{O}_{2}$ & 138.00 & $93-51-6$ \\
\hline & Guaiacols & 0.0037 & $\begin{array}{l}\text { Phenol, } \\
\text { 4-ethyl-2-methoxy- (CAS) } \\
\text { p-Ethylguaiacol }\end{array}$ & $\mathrm{C}_{9} \mathrm{H}_{12} \mathrm{O}_{2}$ & 152 & $2785-89-9$ \\
\hline & Syringols & 0.0157 & $\begin{array}{l}\text { Phenol, } \\
\text { 2,6-dimethoxy- (CAS) 2,6- } \\
\text { Dimethoxyphenol }\end{array}$ & $\mathrm{C}_{8} \mathrm{H}_{10} \mathrm{O}_{3}$ & 154 & $91-10-1$ \\
\hline & $\begin{array}{l}\text { Mixed } \\
\text { oxygenates }\end{array}$ & 0.0088 & $\begin{array}{l}\text { 2-Propanone, } \\
\text { 1-hydroxy- (CAS) Acetol }\end{array}$ & $\mathrm{C}_{3} \mathrm{H}_{6} \mathrm{O}_{2}$ & 74 & $116-09-6$ \\
\hline
\end{tabular}


Table 6 Results of predictive analysis, condensation pressure, condensation pressure and temperature

\begin{tabular}{|c|c|c|c|c|c|c|c|c|c|}
\hline \multirow{2}{*}{ Sample } & \multirow{2}{*}{ Compounds } & \multirow{2}{*}{$\begin{array}{l}\text { Chemical } \\
\text { formula }\end{array}$} & \multirow{2}{*}{ CAS } & \multicolumn{3}{|c|}{ Antoine constant ${ }^{\star}$ ) } & \multirow{2}{*}{$\underset{(\mathrm{mmHg})}{\mathrm{P}_{\mathrm{sw}}}$} & \multirow{2}{*}{$\begin{array}{c}\mathrm{P}_{\mathrm{dp}} \\
(\mathrm{mmHg})\end{array}$} & \multirow{2}{*}{$\begin{array}{l}\mathrm{T}_{\mathrm{dp}} \\
\left({ }^{\circ} \mathrm{C}\right)\end{array}$} \\
\hline & & & & $A$ & $\mathrm{~B}$ & $\mathrm{C}$ & & & \\
\hline \multirow[t]{6}{*}{$\overline{E F B 1}$} & Furan & $\mathrm{C}_{5} \mathrm{H}_{6} \mathrm{O}_{2}$ & $98-00-0$ & 8.21 & 2120.79 & 227.76 & 67238.49 & 31753.63 & 204.22 \\
\hline & Guaiacol & $\mathrm{C}_{7} \mathrm{H}_{8} \mathrm{O}_{2}$ & $90-05-1$ & 7.90 & 2203.80 & 234.22 & 26482.01 & & \\
\hline & Phenols & $\mathrm{C}_{9} \mathrm{H}_{12} \mathrm{O}_{2}$ & $108-95-2$ & 8.92 & 2943.09 & 252.10 & 25681.14 & & \\
\hline & syringol & $\mathrm{C}_{8} \mathrm{H}_{10} \mathrm{O}_{3}$ & $91-10-1$ & 7.06 & 1618.53 & 186.48 & 19852.11 & & \\
\hline & 4-Ethylsyringol & $\mathrm{C}_{10} \mathrm{H}_{14} \mathrm{O}_{3}$ & $14059-92-8$ & 7.84 & 2547.16 & 232.05 & 6396.09 & & \\
\hline & Mixed oxygenates & $\mathrm{C}_{11} \mathrm{H}_{14} \mathrm{O}_{3}$ & $116-09-6$ & 8.20 & 3604.78 & 373.75 & 3472.83 & & \\
\hline \multirow[t]{3}{*}{ EFB2 } & Acid & $\mathrm{C}_{7} \mathrm{H}_{14} \mathrm{O}_{2}$ & $111-14-8$ & 7.38 & 149.41 & 373.75 & 15202439.93 & 10472.14 & 256.02 \\
\hline & Guaiacol & $\mathrm{C}_{8} \mathrm{H}_{10} \mathrm{O}_{2}$ & $93-51-6$ & 8.62 & 3468.88 & 382.59 & 15340.48 & & \\
\hline & Guaiacol & $\mathrm{C}_{9} \mathrm{H}_{12} \mathrm{O}_{2}$ & 2785-89-9 & 8.92 & 2943.09 & 252.10 & 25681.14 & & \\
\hline \multirow[t]{5}{*}{ EFB3 } & Phenol & $\mathrm{C}_{6} \mathrm{H}_{6} \mathrm{O}$ & $108-95-2$ & 7.37 & 1629.40 & 181.37 & 27551.75 & 114559.27 & 154.85 \\
\hline & Guaiacols & $\mathrm{C}_{8} \mathrm{H}_{10} \mathrm{O}_{2}$ & $93-51-6$ & 8.62 & 3468.88 & 382.59 & 3472.83 & & \\
\hline & Guaiacols & $\mathrm{C}_{9} \mathrm{H}_{12} \mathrm{O}_{2}$ & 2785-89-9 & 8.92 & 2943.09 & 252.10 & 3472.83 & & \\
\hline & Syringols & $\mathrm{C}_{8} \mathrm{H}_{10} \mathrm{O}_{3}$ & $91-10-1$ & 7.13 & 1945.46 & 197.36 & 3472.83 & & \\
\hline & Mixed oxygenates & $\mathrm{C}_{3} \mathrm{H}_{6} \mathrm{O}_{2}$ & $116-09-6$ & 8.79 & 2292.46 & 241.70 & 25681.14 & & \\
\hline
\end{tabular}

*) Yaw CL (2009)

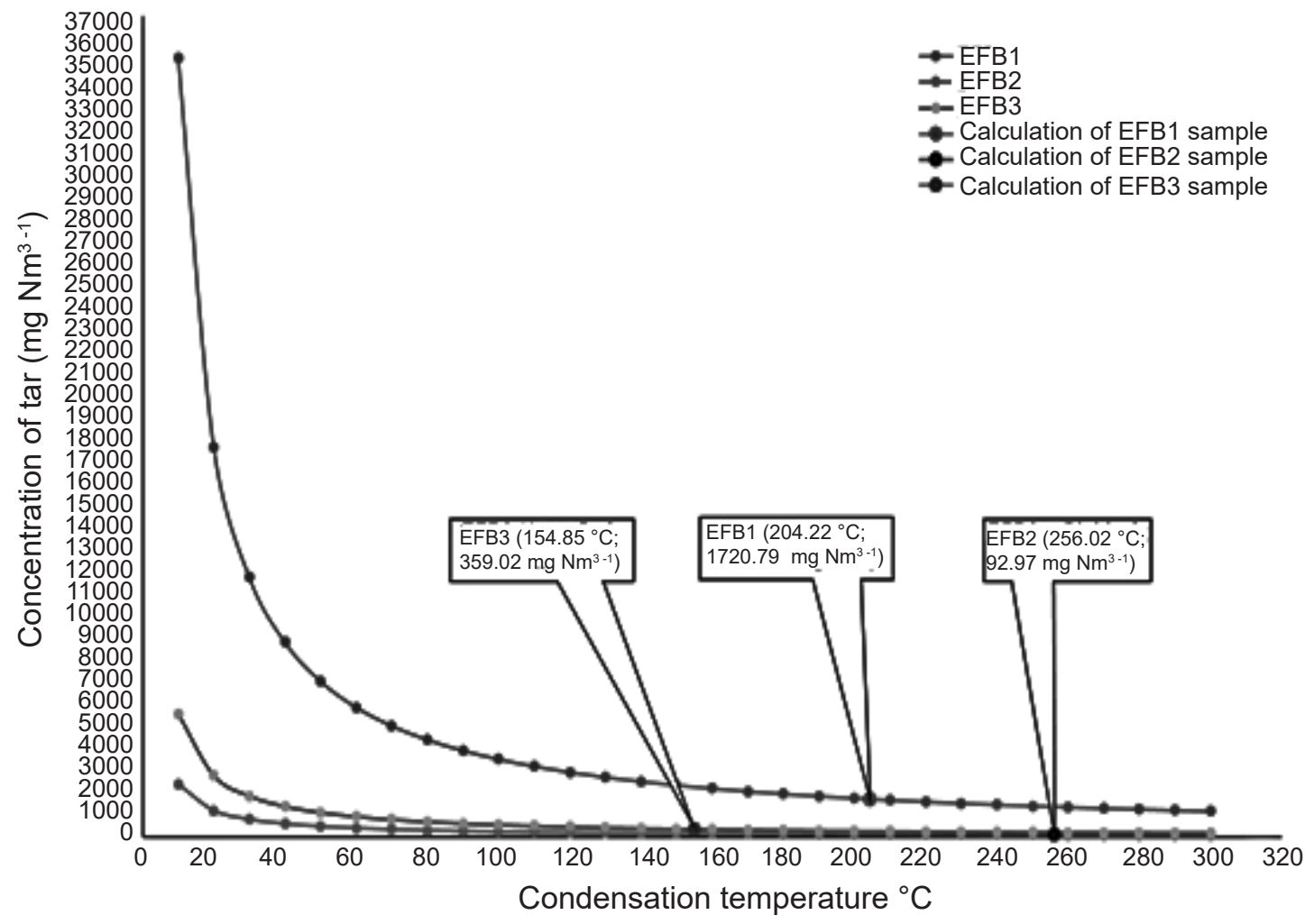

Figure 3 Tar concentration and condensation temperature of pyrolysis EFB .

\section{CONCLUSIONS}

The study can be concluded as follows: the proximate analysis is displayed in wet bases (wb), while the ultimate analysis in dry bases $(\mathrm{db})$. The composition of the efb was found to be $52 \pm 8 \%$ (c), $7.1 \pm 0.5 \%$ (h), $2.3 \pm 0.4 \%(n), 0.5 \pm 0.2 \%$ (s) and $35 \pm 4$ (o); while the ash was $6 \pm 2 \%$, fixed carbon (fc) $17 \pm 1 \%$ and volatile matter (vm) 
$73 \pm 4 \%$; tar compounds produced from pyrolysis at $400{ }^{\circ} \mathrm{C}$, in the form of an oxygenate mixture are classified as first class (class 2) tar compounds which generally consist of phenol compounds (ketones, phenols, and guaiacols); the condensation temperature and the amount of tar concentration in the gas from the pyrolysis of the EFB1sample are $204.22^{\circ} \mathrm{C}$, tar $1720.79 \mathrm{mg} \mathrm{Nm}^{3-1}$ ); $256.02{ }^{\circ} \mathrm{C}$, tar 92.97 mg Nm${ }^{3-1}$ (EFB2 sample); and $154.85^{\circ} \mathrm{C}$, tar $359.02 \mathrm{mg} \mathrm{Nm}^{3-1}$ (EFB3 sample).

\section{ACKNOWLEDGEMENTS}

This research was supported by Ministry of Finance of the Republic of Indonesia with Indonesia Endowment Fund for Education (LPDP-Lembaga Pengembangan Dana Pendidikan) and Ministry of Research, Technology and Higher Education of the Republic of Indonesia.

\section{REFERENCES}

Abdullah N, Sulaiman F, Gerhauser H. 2011. Characterisation of oil palm empty fruit bunches for fuel application. J Phys Sci. 22(1):1-24.

Abdulrazik A, Elsholkami M, Elkamel A, Simon L. 2017. Multi-products productions from Malaysian oil palm empty fruit bunch (EFB): analyzing economic potentials from the optimal biomass supply chain. J Clean Prod. 168(2017):131-148. DOI: 10.1016/j. jclepro.2017.08.088.

Alias N , Ibrahim N, Hamid MKA. 2014. Pyrolysis of oil palm empty fruit bunch by thermogravimetric analysis. the $6^{\text {th }}$ internasional conference on applied Energy-ICAE2014. Energy Procedia. 61(2014):2532-2536.

Chew JJ, Doshi V, Yong ST, Bhattacharya S. 2016. Kinetic study of torrefaction of oil palm shell, mesocarp and empty fruit bunch. JTAC. 126(2):709-715. DOI:10.1007/s10973-016-5518-3.

Erlich C, Fransson TH. 2011. Downdraft gasification of pellets made of wood, palm-oil residues respective bagasse: Experimental study. Appl Energy. 88:899-908. DOI: 10.1016/j.apenergy.2010.08.028.

Gabra M, Pettersson E, Backman R, Kjellstrom B. 2001. Evaluation of cyclone gasifier performance for gasification of sugar cane residue-Part 1 : gasification of bagasse. Biomass Bioenergy. 21(5):351-369. DOI: 10.1016/ S0961-9534(01)00043-5.

Geng A. 2013. Conversion of oil palm empty fruit bunch to biofuels. London (UK): IntechOpen Limited. p.479-490. DOI: $10.5772 / 53043$.

Hamzah MMB. 2008. The production of ecofiber from palm oil empty fruit bunch, In: Universiti Malaysia Pahang [online]. Available: http://umpir.ump. edu.my/521. accessed 5 Feb 2011.

Han J, Kim J. 2018. Process simulation and optimization of 10-MW EFB power plant. Computer Aided Chemical Engineering Vol. 43. p.723-729.

Idris SS, Rahman NA, Ismail K. 2012. Combustion characteristics of $\mathrm{Ma}$ laysian oil palm biomass, sub-bituminous coal and their respective blends via thermogravimetric analysis (TGA). Bioresour Technol. 123:.581-591. DOI: 10.1016/j.biortech.2012.07.065.

Idris SS, Rahman NA, Ismail K, Alias AB, Rashid ZA, Aris MJ. 2010. Investigation on thermochemical behaviour of low rank Malaysian coal, oil palm biomass and their blends during pyrolysis via thermogravimetric analysis (TGA). Bioresour Technol. 101(12):4584-4592. DOI: 10.1016/j.biortech.2010.01.059.

Kerdsuwan S, Laohalidanond K. 2011. Renewable energy from palm oil empty fruit bunch. In: Nayeripour M, editor. 
Renewable energy: trends and applications. Shanghai $(\mathrm{CN})$ : InTech. p. 123-150.

Khor KH, Lim KO, Zainal ZA. 2009. Characterization of bio-oil: a byproduct from slow pyrolysis of oil palm empty fruit bunches. Am J Appl Sci. 6(9):16471652.

Kim JH, Jeong TY, Yu J, Jeon $\mathrm{CH}$. 2019. Influence of biomass pretreatment on co-combustion characteristics with coal and biomass blends. JMST. 33(5):2493-2501. DOI: 10.1007/ s12206-019-0446-3.

Lahijani P, Zainal ZA. 2011. Gasification of palm empty fruit bunch in a bubbling fluidized bed: a performance and agglomeration study. Bioresour Technol. 102(2011):2068-2076.

Lee YJ, Choi JW, Park JH, Namkung H, Song GS, Park S, Lee DW, Kim JG, Jeon $\mathrm{CH}$, Choi YC. 2018. Techno-economical method for the removal of alkali metals from agricultural residue and herbaceous biomass and its effect on slagging and fouling behavior. Washington (DC): ACS.

Lisandy KY, Kim GM, Kim JH, Kim GB, Jeon $\mathrm{CH}$. 2017. Enhanced accuracy of the reaction rate prediction model for carbonaceous solid fuel combustion. Energy Fuels. 31(5):5135-5144. DOI $: 10.1021 / a c s . e n e r g y f u e l s .7 b 00159$.

Milne TA, Evan RJ, Abatzoglu N. 1998. Biomass gasifier "Tars": their nature, formation and convertion. Colorado (US): National Renewable Energi Laboratory.

Mohammed MAA, Salmiaton A, Azlina WAKGW, Amran MSM. 2012. Gasification of oil palm empty fruit bunches: A characterization and kinetic study. Bioresour Technol. 110:628-636. DOI: 10.1016/j.biortech.2012.01.056

Morf P, Hasler P, Nussbaumer T. 2002. Mechanisms and kinetics of homoge- neous secondary reaction of tar from continuous pyrolysis of woods chip. Fuel 81(7):843-853. DOI: 10.1016/ S0016-2361(01)00216-2.

Nyakuma BB, Ahmad A, Johari A, Abdullah A, Oladokun O, Bello A, Alkali H, Ahmed SI. 2015. Kinetics analysis of oil palm empty fruit bunch (OPEFB) pellets as feedstock for pyrolysis. PeerJ PrePrints 3:e1150v1. DOI: https://doi. org/10.7287/peerj.preprints.1150v1.

Nyakumaa BB, Joharia A, Ahmada A. 2013. Thermochemical analysis of palm oil wastes as fuel for biomass gasification. J Teknol (Sci Eng). 62(3):73-76.

Law KN, Daud WRW, Ghazali A. 2007. Morphological and chemical nature of fiber strands of oil palm empty-fruitbunch (OPEFB). Bioresources. 2(3)351-362.

Omar R, Idris A, Yunus R, Khalid K, Isma MIA. 2011. Characterization of empty fruit bunch for microwave-assisted pyrolysis. Fuel. 90:1536-1544. DOI: 10.1016/j.fuel.2011.01.023.

Paul T, Williams PT, Horne PA. 1994. Analysis of aromatic hydrocarbons in pyrolytic oil derived from biomass. J Anal Appl Pyrol. 31(1995):15-37.

Rabou, Luc PLM, Robin WR, Zwart, Berend J, Vreugdenhil, Lex Bos. 2009. Tar in biomass producer gas, the energy research centre of the Netherlands (ECN) experience: an enduring challenge. Energy Fuels. 23(12):6189-6198.

Raju M, Tambunan AH, Setiawan RPA. 2016. Karakterisasi arang dan gasgas hasil pirolisis limbah kelapa sawit. JTEP. 4(2):153-160. DOI: 10.19028/ jtep.04.2.

Richardson Y, Drobek M, Julbe A, Blin J, Pinta F. 2015. Biomass gasification to produce syngas. in: recent advances in thermochemical conversion of biomass. Edited by Ashok Pandey, Thallada Bhaskar, Michael Stöcker, Rajeev 
K Sukumaran. Netherlands (NL): Elsevier. p. 213-245. DOI: 10.1016/B978-0444-63289-0.00008-9.

Ruengvilairat $\mathrm{P}$, Tanatavikorn $\mathrm{H}$, Vitidsant T. 2012. Bio-oil production by pyrolysis of oil palm empty fruit bunch in nitrogen and steam atmospheres. J Sustain Bioenergy Syst. 2(4):75-85.

Shin T, Hajime O, Chuichi W. 2011. Pyrolysis-GC/MS data book of synthetic polymers: pyrograms, thermograms and MS of pyrolyzates. Oxford (UK): Elsevier

Sukiran MA, Loh SK, Bakar NA, Choo YM. 2011. Production and characterization of bio-char from the pyrolysis of empty fruit bunches. Am J Appl Sci. 8(10):984-988.

Tang DYR, Islam A, Yap YHT. 2017. Biooil production via catalytic solvolysis of biomass. RSC Adv. 7:7820-7830. DOI: https://doi.org/10.1039/C6RA27824H.

Yang H, Yan R, Chin T, Liang DT, Chen H, Zheng C. 2004. Thermogravimetric analysis-fourier transform infrared analysis of palm oil waste pyrolysis. Energy Fuels. 18:1814-1821. DOI: 10.1021/ef030193m.

Yaws CL. 2009. Transport properties of chemicals and hydrocarbons: viscosity, thermal conductivity, and diffusivity of $\mathrm{C} 1$ to $\mathrm{C} 100$ organics and $\mathrm{Ac}$ to $\mathrm{Zr}$ inorganic's. New York (NY): William Andrew Inc.

Zhang X, Rajagopalan K, Lei H, Ruan R, Sharma, BK. 2017. An overview of a novel concept in biomass pyrolysis: microwave irradiation. Sustaine Energy Fuels. 1(8):1664-1699. DOI: 10.1039/ C7SE00254H. 